かけることの三つを特徽としている，電解加工はくほ みや等高面の加工に適し, 電極の工具によるプランジ 加工と電解液の急速な偱環作用に特徴がある。電解液 には電解生成物を溶解する性質のものを用い，また工 具の消耗は少量である．化学ミリングは適当な試薬を 用い漫食により部品の成形走行なうもので，薄い部分 や複雑な形状の加工に向いている，超音波加工は工 具と加工物との間にと粒を浮かせた液を流し，細かい 衝撃を与えることによって硬質材料を加工することを 目的としたもので彫刻, 薄切り, 穴あけ等に応用でき る.電子ビーム加乙は金属の溶融と溶接のほか穴あ 村，スロッチング，切削作業に応用される。蓺の影響 をさけるため，ビームはパルス状に発生させる。プラ ズマ切削は電極からノズルを経てプラズマを噴出さ せ，その高温によって鉄板の切断，耐火性材料の型彫 り等ができる.プラズマアークの温鹿は非常に高く空 気中で約 $5000^{\circ} \mathrm{C}$ に達する。 [金井 昌彦]

\section{9 .054}

※[1043]切削液に関する研究展望 [P.A. Smith, C.A. Sluhan, \& R.G. Moyer, Mech. Engng., 19616, Vol. 83, No. 6, p. 57〜 58] 本論文は最近の切 削液に関する研究を展望したものである。この部門で の研究はあまり活発でないけれども，参考文献の夕、イ トルをあげてみると，

（1）切削液の冷却特性に関する研究（A.S.T.E.）

(2) 水溶性切削液のスポイレージの抑制に関する研 究 (Lubric. Engng.)

(3) 切削液の諸特性 (A.S.L.E.)

(4) 超高力鋼切削時に洽却剤として炭酸ガスを使用 する研究 (Aircr. prod.)

(5) 切削液に Nitroparaffine を添加用として使用 する場合の研究 (Lubric. Engng.)

(6)切削液を評価する試験法に関する研究 (Lubric. Engng.)

そなり，それぞれについて簡単に述べている。

\section{9-229.31:621.319}

[西村 正巳]

$\dagger[1044]$ 静電チャック [Aircr. Prod., 1961-5, Vol. 23 , No. 5, p. 158 161, 図 7] 平面研削作業に際 して, 静電エネルギを用いて, 非硫性体のチャックを 行なう方法が開発された。原理は，エポキシ樹脂をテ ーブル上に塗布し，これを $0.025 \mathrm{~mm}$ の厚さに研削 後, 絶縁液を下面に好った工作物を載せ，工作物とテ ーブル間に静電荷を加えこの静電力によって，チャ ックするものである. 工作物は物理的接触によって， チャック側面から荷電される。

この方法は,アメリカでは黄銅, $\mathrm{A} 1$ 合金, ステンレ ス鋼部品に対し，既に奉用されている。消磁の必要が ないので，鋼部品に㸚しても注目されている。

欠点は, 吸引力を $1 \mathrm{~kg} / \mathrm{cm}^{2}$ とした場合, 約 $2000 \mathrm{~V}$, $10 \mathrm{~kg} / \mathrm{cm}^{2}$ にした場合には，6000 V 以上の高圧が必 要となること（訳者概算）および，エポキシ被膜を週 は一度くらいずつ塗布研削せ补ばならないことであ z.

[八木. 博]

\subsection{7 .6}

†[1045] Electroforming は実用的か [W.H. Safranek, Prod. Engng., 1961, Vol. 32, No. 23, p.
44〜49, 図 6, 表 4] 従来 Electroforming は多く の工作法の中でもコストがかさむものとされ，よほど 特殊な場合でないと実用されていない。しかし，本論 文では新合金，新しい方法による強度の改善により他 の工作法に比較して十分に対抗できることを強調し， それらの諸点について述いている。すなわち，うま く型を使用すれば経斎的にも十分採算がとれ，実際 に製品の形状が大きい場合，他の工作法よりコスト が低くなる場合がある、コンベアで開発された Niに $7 \sim 10 \% の \mathrm{Mn}$ そ含有させた合金は高張力で残留涮力 す少なく簡単に他の金属に溶着させることができる。

Electroforming がむずかしいような場合でも多種類 の合金の痛を形成させて强度，延性，厚さの均一性を 保持することができる。このほか，型の選択上重要な 諸点, 設計上留意しなければならない諸点をくわしく 述べている。 [无村 正已]

\subsection{5:621.983.4.011}

$※[1046]$ 金属のスピン成形性判定のための新試験法

[R.L. Kegg, Trans. ASME, Series B, 1961-5, Vol. 83, No. 2, p. 119 124, 図 11, 表 2] 昭和 36 年 5 月号 818 ページに紹介した「シャースピン成 形法改善の基礎」の本論文である，著者らにより提案 されているスピン成形性試験が，アルミニりム合金， ステンレス，銅，鋼など 16 種の金属板について試み られ，同じ材料が弓張試験，かたさ試験において示す 諸特性と比較して示されている．提案された試験法が 实用的なものであることが確かめられ，材料が特に強 い方向性を示すものを除いては，引張試験における断 面縮みによって成形性が比較推定できると結論してい る。すなわち，板唇減少率を０１00\% まで徐々に変 化させるため，だ円体マンドレルを用いて試料をシャ ースピン成形し，その限界板厚減少率 $R \%$ と，単軸 引張試験における破断時の断面縮み率 $q \%$ のあいた に，次の実験式を得ている（板厚 $1 / 4 \mathrm{in}$ ).

$$
R=\frac{q}{0.17+\frac{q}{100}}
$$

ここで $q$ が比較的大きい場合 ( $80 \%$ 前後)には， $R \fallingdotseq$ $q$ となり，qが小さい場合には $R>q$ となるが，この 原因汕破断の形式の相違によるものと示唆されてい る。また，過圧下により薄い壁厚までスピン成形する と大きな変形分得られ，逆に圧下不足の場合にはその 限界值が小さくなる事実を認め，これを変形をうけつ つ亦る領域にはたらく平均圧縮汒力の大小によって説 明しようとしている。

[堤 成 晃]

\subsection{6 .45}

†[1047]板金の爆発加工に用いられるエポキシ系ダ イス [R.J. Salter, Brit. Plast., 1961-3, Vol. 34, No. 3, p. 116] 板金加工としての爆発成形にエポ キシ樹脂積層がいかに利用されるかが述べられてい る.アルミニウム等はもちろんチタニウム, ステンレ 又鋼の成形は水中爆発で水を媒介としてエネルギを伀 えて瞬間的に成形を完了する。その際の型材として鉄 鋼やカークサイト等に対してエポキシ系積曆材は安何 で迅速に利用し得, 航空機関のノーズコーン成形用ダ イスとして実用されつつある。エポキシ樹脂積層材で ダイスを製作するにはだいたい次のような順序で行 